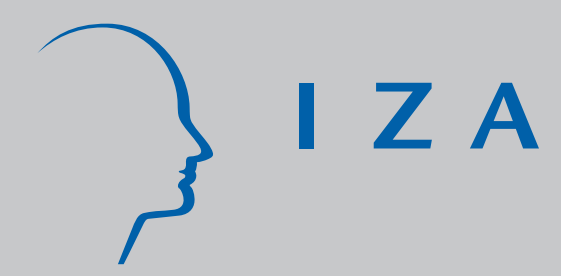

IZA DP No. 544

Disentangling the Minimum Wage Puzzle: An Analysis of Worker Accessions and Separations

Pedro Portugal

Ana Rute Cardoso

August 2002 


\title{
Disentangling the Minimum Wage Puzzle: An Analysis of Worker Accessions and Separations
}

\author{
Pedro Portugal \\ Banco de Portugal and Universidade Nova de Lisboa \\ Ana Rute Cardoso \\ Universidade do Minho, CEPR and IZA Bonn
}

\author{
Discussion Paper No. 544 \\ August 2002
}

\author{
IZA \\ P.O. Box 7240 \\ D-53072 Bonn \\ Germany \\ Tel.: +49-228-3894-0 \\ Fax: +49-228-3894-210 \\ Email: iza@iza.org
}

This Discussion Paper is issued within the framework of IZA's research area Welfare State and Labor Market. Any opinions expressed here are those of the author(s) and not those of the institute. Research disseminated by IZA may include views on policy, but the institute itself takes no institutional policy positions.

The Institute for the Study of Labor (IZA) in Bonn is a local and virtual international research center and a place of communication between science, politics and business. IZA is an independent, nonprofit limited liability company (Gesellschaft mit beschränkter Haftung) supported by the Deutsche Post AG. The center is associated with the University of Bonn and offers a stimulating research environment through its research networks, research support, and visitors and doctoral programs. IZA engages in (i) original and internationally competitive research in all fields of labor economics, (ii) development of policy concepts, and (iii) dissemination of research results and concepts to the interested public. The current research program deals with (1) mobility and flexibility of labor, (2) internationalization of labor markets, (3) welfare state and labor market, (4) labor markets in transition countries, (5) the future of labor, (6) evaluation of labor market policies and projects and (7) general labor economics.

IZA Discussion Papers often represent preliminary work and are circulated to encourage discussion. Citation of such a paper should account for its provisional character. A revised version may be available on the IZA website (www.iza.org) or directly from the author. 


\section{ABSTRACT \\ Disentangling the Minimum Wage Puzzle: An Analysis of Worker Accessions and Separations*}

Changes in the legislation in the mid-80s in Portugal provide remarkably good conditions for analysis of the employment effects of mandatory minimum wages, as the minimum wage increased sharply for a very specific group of workers. Relying on a matched employer employee panel data set, we model gross worker flows - accessions and separations - in continuing firms, as well as in new firms and those going out of business, using a count regression model applied to proportions. Employment trends for teenagers, the affected group, are contrasted to those of older workers, before and after the raise in the youth minimum wage. The major effect on teenagers of a rising minimum wage is the reduction of separations from the employer, which compensates for the reduction of accessions to new and continuing firms. In this sense, our results can reconcile some of the previous evidence that has been presented in the empirical literature when analyzing the aggregate impact of the minimum wage on youth employment without decomposing it by type of worker flow.

JEL Classification: D21, J23, J38

Keywords: minimum wage, employment

Pedro Portugal

Banco de Portugal

Av. Almirante Reis 71

1150-165 Lisboa

Portugal

Email: jppdias@bportugal.pt

\footnotetext{
* Part of this work was carried out while the second author was visiting the Economics Program, RSSS, Australian National University, whose financial support and stimulating hospitality are gratefully acknowledged. The support while visiting the Bank of Portugal is acknowledged as well. We would like to thank Orley Ashenfelter, David Autor, Olivier Blanchard, Dan Black, Bruce Chapman, Denise Doiron, Dan Hamermesh, Francis Kramarz, José A. Machado, Alan Manning, José Mata, Ray Rees, and José Varejão for their comments. We also thank seminar participants at Princeton University, University of Pompeu Fabra, Universidade Nova de Lisboa, Bank of Italy, IZA, Bank of Portugal, Australian National University and Newcastle University. Helpful comments from participants at the meetings of the European Association of Labour Economists (Jivaskyla), Applied Econometric Association (Brussels), Sociedade Portuguesa de Investigacão em Economia (Aveiro), the International Conference on Comparative Analysis of Enterprise (micro) Data (Aarhus), and the New Zealand Conference on Database Integration and Linked Employer-Employee Data (Wellington) are also acknowledged. We are indebted to Lucena Vieira for excellent research assistance. We thank the financial support from the Fundacão para a Ciência e a Tecnologia. The usual disclaimer applies.
} 


\section{Introduction}

In this study the dynamics of employment at the firm level following a sharp increase in the minimum wage is analyzed. Several novel aspects are introduced in the empirical analysis of the topic.

First, the change in the legislation under analysis provides remarkably good conditions for economic analysis, since the increase in the mandatory minimum wage was large, unpredictable, and it affected only a very specific group of workers. Indeed, in 1987 the minimum wage for workers aged 17 increased in Portugal by 50 percent, due strictly to changes in the legislation, and for workers aged 18 or 19 it was raised from 75 percent to the full minimum wage rate, therefore increasing by 33 percent.

Second, the analysis relies on a panel of linked employer-employee data, covering in each year nearly all of the wage earners in the private sector (over two million workers), an outstanding data set. Every firm with wage-earners is legally obliged to reply to this inquiry by the Ministry of Employment, and the response rate is thus extremely high.

Third, the study handles issues that have not previously been explored in the literature. By explaining employer behavior regarding both accessions and separations, and focusing not just on firms remaining in business, but also on new firms and those closing down, this study adds to the previous literature that has explained net job flows at the firm level (Card and Krueger 1994, Katz and Krueger 1992, Pereira 2002). ${ }^{1}$ We can therefore address the minimum wage puzzle, by identifying exactly where and how the minimum wage bites: do employers dismiss mainly youngsters, following a rise in the youth minimum wage? Or do youngsters become under-represented among the newly hired workers? Do firms that are about to be set up, which are free to choose their labor force from the available pool of workers, hire relatively fewer youngsters than comparable firms did before the minimum wage was raised? Does a rising minimum wage place unbearable

\footnotetext{
${ }^{1}$ See, however, Card and Krueger (1994) for a study of the impact of changes in minimum wages on entries and exits of McDonalds franchises.
} 
constraints on firms, contributing to firm closure? Identification of the precise source for changing employment levels can reconcile some of the evidence that has previously been presented in the literature as contradictory.

We will also rely on micro data on workers to follow a line of analysis previously used by Abowd et al. (2000), Zavodny (2000) and Currie and Fallick (1996). At the individual level, we can provide a direct answer to the question: are the workers directly affected by a rise in the minimum wage less likely to keep their jobs?

Therefore, in the current study, two types of constraints traditionally faced by labor economists in the empirical analysis of the minimum wage are relaxed. First, the impact of the minimum wage is usually hard to isolate from that of other economic forces. Ideally, the conditions for quasi-experiments should be met, in which case changes in the minimum wage would affect strictly a specific group of workers, subject to conditions otherwise similar to other workers, a situation that very rarely occurs in economics. The studies by Card and Krueger $(1994,1995)$ and Katz and Krueger (1992) have become well-known examples of that methodology, as their work generated an intense debate. ${ }^{2}$ Second, even when changes in the minimum wage provide good conditions for economic analysis, the study to be undertaken still depends crucially on the data available, in particular its quality and detail. ${ }^{3}$ On both of these fronts, our study relies on unusually favorable conditions, enabling the analysis to progress into directions left unexplored by previous studies.

Section 2 describes the institutional framework in Portugal and the major changes that have taken place with respect to the mandatory minimum wage. Sections 3 and 4 provide an aggregate perspective on changes in the wage distribution and in employment, showing a high degree of compliance with the new legislation and a positive impact of rising minimum wages on employment. Section 5.1 models job accessions and job separations in continuing firms, whereas

\footnotetext{
${ }^{2}$ See for example the Review Symposium in the Industrial and Labor Relations Review in July 1995, Keenan (1995), Neumark and Wascher (2000), Burkhauser et al. (2000), Card and Krueger (2000), Machin and Manning (1996), Deere et al. (1995), Dolado et al. (1996).

${ }^{3}$ Meyer and Wise $(1983 \mathrm{a}, \mathrm{b})$ have developed a methodology to estimate the impact of the minimum wage on employment and the wage distribution using just one cross-section of data. Their methodology is discussed in Dickens et al. (1998).
} 
section 5.2 performs a similar exercise for new firms and for firms closing down. Worker turnover is the subject of section 6. An extension of the theoretical model of Burdett and Mortensen (1998) is highlighted in section 7, as it provides very clear predictions that fit well the empirical evidence disclosed for Portugal. The last part of the paper presents concluding comments.

\section{Institutional framework}

In Portugal, a mandatory minimum wage was set for the first time in 1974, covering solely workers aged 20 or older and excluding agriculture and household services. Ever since, it has been annually updated by the parliament, under government proposal. ${ }^{4}$ Decisions on the level of the minimum wage are taken on a discretionary basis, usually taking into account past and predicted inflation and a consultation with the social partners. It is defined as a monthly wage. Since it was first enacted, the minimum wage has undergone several changes ${ }^{5}$, the major one regarding the age coverage. Indeed, the ages subject to exemption, as well as the percentage of exemption, have changed several times, and a clearer description can be provided by a table, where the major changes are highlighted in bold.

\begin{tabular}{|r||c|c|c|c|c|c|}
\hline \multicolumn{1}{|c||}{ Year } & \multicolumn{6}{c|}{ Age Group } \\
\hline & 15 & 16 & 17 & 18 & 19 & $20-25$ \\
\hline \hline 1979 to 1986 & 50 & 50 & 50 & 75 & 75 & 100 \\
1987 & 50 & 50 & 75 & $100^{*}$ & $100^{*}$ & $100^{*}$ \\
1988 & 75 & 75 & 75 & $100^{*}$ & $100^{*}$ & $100^{*}$ \\
\hline
\end{tabular}

Table 1: Share of the general minimum wage enforced, according to the age of the worker, in percentage. Note:* 80 if apprentice. Source: Portugal, Diário da República, several issues.

Three changes in the legislation have yielded remarkable wage increases for the ages involved:

- first of all, in 1987 the minimum wage for workers aged 17 increased by 50 percent due to changes in the legislation ceteris paribus, as it was raised from half to 75 percent of the full minimum wage;

\footnotetext{
${ }^{4}$ The only exceptions were 1982, when it was not updated, and 1989, when it was updated twice.

${ }^{5}$ Fully described in appendix.
} 
- second, also in 1987, the minimum wage for workers aged 18 or 19 was raised from 75 percent of the minimum wage to the full minimum, therefore increasing by 33 percent;

- the third change took place the following year, in 1988, as the minimum wage for workers aged 16 or less was raised from 50 percent to 75 percent of the full minimum, thus increasing by 50 percent.

Exceptions could, however, apply to the second change described, if the worker was formally classified as an apprentice, in which case he/she would be entitled to 80 percent of the general minimum wage, instead of the full rate. This exemption could undermine the impact of the rise in the minimum wage that we intend to study, if employers had room to change the occupational category of the worker to an apprentice, in order to get away without paying him/her the full minimum wage, an issue to be addressed and checked in the next section.

This study concentrates on the changes that took place in 1987, as they provide good conditions for economic analysis. In her study, Pereira (2002) used the same change in the legal framework described, arguing that it defines the setting for a quasi-experiment in economics (for more details, see Pereira (2002)).

\section{Overview: aggregate data suggest that youth employ- ment increased following a sharp rise in the youth min- imum wage}

Preliminary evidence on the impact of the rise in the minimum wage, based on aggregate figures (tables 2 and 3 and figure 1), indicates that compliance with the minimum wage legislation was high and seems to suggest that traditional economic theory is challenged, in the sense that the rise in the minimum wage did not lead to declining employment. Note first the impact of the legal changes on the average wage of the different age groups, relying on three cross-sections of data.

As expected, wages increased most sharply precisely for the groups of workers affected by the rise in the minimum wage (see highlights in bold in table 2). For 


\begin{tabular}{|r||l|l|l|}
\hline \multicolumn{1}{|c||}{} & \multicolumn{3}{c|}{ Wage growth factor } \\
\hline Age & 1987 & 1988 & 1989 \\
\hline \hline 16 & 1.16 & 1.21 & 1.17 \\
17 & 1.21 & 1.14 & 1.15 \\
18 & 1.21 & 1.12 & 1.13 \\
19 & 1.18 & 1.12 & 1.13 \\
20 & 1.15 & 1.11 & 1.13 \\
21 & 1.14 & 1.12 & 1.12 \\
22 & 1.14 & 1.12 & 1.13 \\
23 & 1.14 & 1.12 & 1.14 \\
24 & 1.14 & 1.12 & 1.14 \\
$25-29$ & 1.14 & 1.10 & 1.13 \\
$30-34$ & 1.15 & 1.10 & 1.15 \\
$35-39$ & 1.14 & 1.09 & 1.13 \\
$40-65$ & 1.16 & 1.11 & 1.14 \\
\hline
\end{tabular}

Table 2: Growth in the average wage of full-time wage earners, by age group, 1986-1989. Source: Computations based on Portugal, M TS (1986-1989). Wages refer to the gross base monthly wage, and the change is computed as $\frac{w_{a, t}}{w_{a, t-1}}$, where $w$ stands for the average wage of the age group $a$, and the subscript $t$ denotes time.

example, between 1986 and 1987, the average wage for workers aged 17, 18 or 19 increased the most, while all the other age categories had a much lower and more homogeneous wage growth. The rise in the legal minimum wage thus seems to have had a relevant impact on the wages of the eligible workers, indicating that subminimum wages had been widespread among teenagers ${ }^{6}$ and that the possibility to register a worker as an apprentice was not extensively used by employers. Indeed, the share of apprentices in the age categories directly affected by the change in the legislation did not increase during this period (see appendix $\mathrm{C}$ ). The same pattern holds for the subsequent year, as the groups of workers affected by changes in the minimum wage - those aged 16 or less — saw their average wage rise the most.

Visual inspection of the wage distribution in figure 1 stresses the relevance of the changes that took place. In 1986, the wage distribution for teenagers showed a sharp peak at 75 percent of the national minimum wage, that is, the sub-minimum allowed for workers aged 18 or 19. The distribution presented a less pronounced peak at the full minimum wage. By 1987, the peak at the sub-minimum wage level had almost vanished, and the share of teens at the minimum wage had increased

\footnotetext{
${ }^{6}$ In 1986 , the share of workers aged 17,18 and 19 earning sub-minimum wages was 84 percent, 63 percent and 46 percent, respectively.
} 
sharply. The kernel plot (produced with a common bandwidth) therefore indicates that the rise in the applicable minimum wage shifted sub-minimum teenager wages to the new minimum wage level, and thus compliance to the new regulation was widespread.

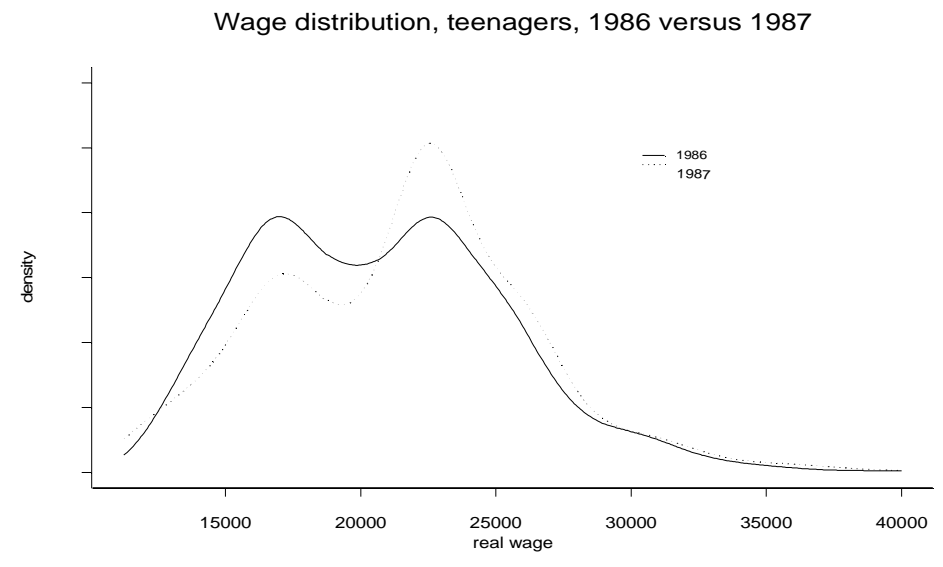

Figure 1: Wage dist ribut ion, t eenager s, 1986 ver sus 1987. Note: Refers to teenagers aged 17 to 19 and to gross base monthly wage, in 1986 prices (PTE).

While total employment increased by 3.3 percent between 1986 and 1987 (table 3), the number of jobs taken by workers aged 17 to 19 increased more sharply, by 4.3 percent to 6.1 percent. Nevertheless, the group aged 20 to 23 presented even higher employment growth rates. The following year, while total employment increased by 1.2 percent, the youngest workers had a much higher employment growth, which compensated for the decline in the employment of prime-age workers. This level of analysis therefore does not suggest the existence of an aggregate negative impact on employment resulting from the sharp rise in the minimum wage for specific age groups.

\section{An accounting framework}

A more telling way to isolate the impact of the change in the minimum wage legislation on employment and wages is obtained via the estimation of the following 


\begin{tabular}{|r||c|c|c|}
\hline \multicolumn{1}{|c||}{} & \multicolumn{3}{c|}{ Employment growth factor } \\
\hline Age & 1987 & 1988 & 1989 \\
\hline \hline 16 & 1.060 & 1.148 & 1.092 \\
17 & 1.052 & 1.094 & 1.119 \\
18 & 1.043 & 1.090 & 1.106 \\
19 & 1.061 & 1.066 & 1.108 \\
20 & 1.086 & 1.042 & 1.108 \\
21 & 1.082 & 1.051 & 1.088 \\
22 & 1.109 & 1.054 & 1.099 \\
23 & 1.063 & 1.083 & 1.095 \\
24 & 1.055 & 1.041 & 1.136 \\
$25-29$ & 1.014 & 0.995 & 1.071 \\
$30-34$ & 1.023 & 1.002 & 1.032 \\
$35-39$ & 1.029 & 0.983 & 1.001 \\
$40-65$ & 1.027 & 0.996 & 1.049 \\
total & 1.033 & 1.012 & 1.077 \\
\hline
\end{tabular}

Table 3: Growth in number of full-time wage-earners by age groups, 1986-1989. Source: Computations based on Portugal, MTS (1986-1989). Employment growth was computed as $\frac{L_{a, t}}{L_{a}, t-1}$, where $L_{a}$ stands for employment of age group $a$, and the subscript $t$ denotes time.

wage and employment equations:

$$
\begin{gathered}
\Delta e_{a, t}=\alpha_{a}+\lambda_{t}+\beta T_{a, t}+u_{a, t} \\
\Delta w_{a, t}=\alpha_{a}^{0}+\lambda_{t}^{0}+\beta^{0} T_{a, t}+v_{a, t} \\
\Delta e_{a, t}=\eta \Delta \hat{w_{a, t-1}}+\alpha_{a}^{\infty}+\lambda_{t}^{\infty}+z_{a, t}
\end{gathered}
$$

where $\Delta e_{a, t}$ denotes the log employment change for workers aged $a$ at year $t$. $\alpha_{a}$ and $\lambda_{t}$ correspond to the age and time dummies, respectively. $T$ is a binary variable that stands for the treatment group. In other words, $T$ equals one for the (teen)age group affected by the change in the legislation, at the relevant year. $u_{a, t}$ is a random error term. In the second equation, $\Delta w_{a, t}$ stands for the log change in wages for workers aged $a$ at year $t$. In the third equation, the estimated values from the second equation are used in order to instrument the wage variable.

Aggregating the employment and wage information into 19 age cells for each year over the period of 1985 until 1989, the estimation results in table 4 indicate that in 1987 the wage rates of teenagers increased 4.6 percent above their similarly 
aged counterparts in other years. In line with our previous discussion, employment increased sharply (5.7 percent) in 1988 for the affected group of workers. These results lead to an imprecisely estimated wage elasticity in the neighborhood of $1 .^{7}$ We take this summary measure as tentative evidence that an increase in the minimum wage may, under certain conditions, increase employment. Our next step is to deepen our investigation in order to show how employment changed.

\begin{tabular}{|r||c|c|c|}
\hline \multicolumn{1}{|c||}{ Variables } & \multicolumn{3}{c|}{ Dependent Variable } \\
\hline & $\Delta w$ & \multicolumn{2}{|c|}{$\Delta e$} \\
\hline \hline Treatment group dummy & 0.046 & & \\
Equals one for those aged 17 to 19 in 1987 & $(008)$ & & \\
Treatment group dummy & & 0.057 & \\
Equals one for those aged 17 to 19 in 1988 & & $(0.024)$ & \\
Instrumented wage changes & & & 1.069 \\
Age dummies & Present & Present & Present \\
Time dummies & Present & Present & Present \\
N (Age*Time) & 95 & 95 & 76 \\
\hline
\end{tabular}

Table 4: Regression of employment and wage changes on age and time dummies, 1985-1989. Computations based on workers aged 16 to 35. Standard errors in parentheses.

\section{Modeling both sides of the recruitment policy of the firm: worker accessions versus worker separations}

Firms may change the composition of their labor force following a rise in the minimum wage for a particular group of workers, namely dismissing workers whose marginal productivity falls below the new minimum wage or avoiding hiring those workers. This section models worker flows distinguishing between: hirings by continuing firms; hirings by companies newly set up; separations from continuing firms; and layoffs from companies that close down.

We will concentrate on the share of teenagers in total job accessions/separations involving workers aged up to 35 years. Whereas overall figures for job accessions and separations may be influenced by the business cycle, concentrating on the share of teenagers in those flows can highlight changes in employer policies following the

\footnotetext{
${ }^{7}$ The 95 percent confidence interval has a lower band at 0.159 and an upper band at 1.979 .
} 
rise in the youth minimum wage. In fact, considering just the flows for workers aged up to 35 we are comparing similar groups, expected to be affected in a similar way by trends in the business cycle. ${ }^{8}$ Insight into the impact of minimum wages on worker flows was obtained via regression analysis. A Poisson regression model applied to grouped data was employed. The size of the flow of teenage workers was modeled as

$$
y_{i} \sim P\left[\mu_{i}=\lambda_{i}\right]
$$

with

$$
\lambda_{i}=\exp \left(x_{i}^{0} \beta\right) N_{i}
$$

or, in a more convenient reparameterization

$$
\log \left(\lambda_{i}\right)=x_{i}^{0} \beta+\log \left(N_{i}\right)
$$

where $\mu$ is the expected value of the number of events (in this case, the number of teenage workers), $x$ is the vector of explanatory variables, and $\beta$ the vector of corresponding regression coefficients. $N_{i}$ denotes the size of the exposure set in the same unit in which the events occur (in this case, the firm's flow of workers). Note that this approach automatically accommodates the need to properly weight each observation by the size of the total flow of workers (aged less than 35 years).

When modeling trends in continuing firms one has to account for the possibility that there are repeated observations. Firms will be present as long as there are hirings (or separations) in a given year. A natural way to accommodate the longitudinal nature of this data is to specify a model with firm-specific random effects:

$$
y_{i t} \sim P\left[\mu_{i t}=\alpha_{i} \lambda_{i t}\right]
$$

where

$$
\lambda_{i t}=\exp \left(x_{i t}^{0} \beta\right) N_{i}
$$

\footnotetext{
${ }^{8}$ Another reason why we did not include older workers is because we want to minimize the contamination of our results generated by early retirement decisions, a phenomenon that was fairly frequent during this period.

We have extensively searched for evidence of spillover effects on the employment of young adults resulting from a rise in the youth minimum wage, but support for that hypothesis has not been found.
} 
and $\alpha_{i}$ is a random error term, assumed to be gamma distributed with unit mean and variance equal to $1 / \delta$. Integration with respect to $\alpha_{i}$ leads to the unconditional density (Cameron and Trivedi, 1998):

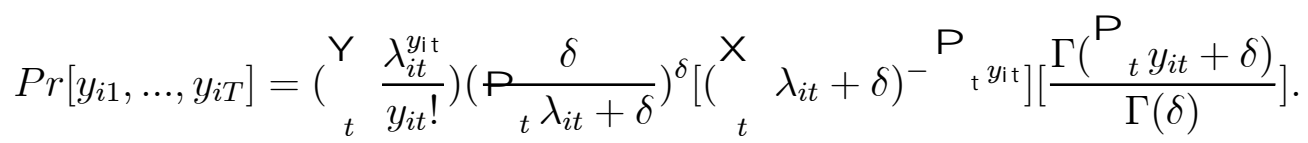

Maximum likelihood estimation of the $\beta$ and $\delta$ parameters is straightforward. The results of both specifications, with and without random effects, are presented for comparison. ${ }^{9}$

Note the similarities and differences between this methodology and the one most often used in the literature. The 'difference in differences' approach compares the before and after treatment situations for the affected group and the control group. In that case, four stocks are considered - the employment level in different years for two different groups. The first difference computes the net employment change for each group, canceling out permanent characteristics of the group. The second difference compares the two groups, canceling out macroeconomic shocks that affect both groups of workers in the same way. Ordinary least squares are used to estimate the model.

Our approach here is, instead, based on flow variables — worker accessions and separations - and therefore the difference in differences methodology is no longer adequate. Instead, the 'first difference' is already accounted for, by considering worker flows. The two groups are compared by computing the share of teenagers in the total flow, and a count data model applied to proportions is estimated. As in the difference in differences approach, permanent heterogeneity across the groups and business cycle effects are accounted for.

\subsection{Gross job flows in continuing firms}

Consider first the recruitment and dismissal policy in continuing firms. The regression in table 5 compares the recruitment policy in 1986, before the change in the minimum wage, with that of 1988, a year and two months after the rise in the

\footnotetext{
${ }^{9}$ Negative binomial models, with and without firm random effects, were estimated as well, with results identical to the ones presented.
} 
minimum wage, and that of 1989, therefore allowing for a longer lag in the impact of the minimum wage on recruitment policies. Data for the control years of 1986 and the years under analysis have been pooled, and year dummy variables aim at capturing the impact of the policy change. The affected group and the control group (workers aged 20 to 34 ) were kept in the sample.

\begin{tabular}{|r||c|c|c|c|}
\hline \multicolumn{1}{|c||}{ Variables } & \multicolumn{2}{c|}{ no random effects } & \multicolumn{2}{c|}{ with random effects } \\
\hline & Coef & Std & Coef & Std \\
\hline \hline year 1988 (dummy) & -0.057 & 0.009 & -0.036 & 0.010 \\
year 1989 (dummy) & -0.065 & 0.009 & -0.043 & 0.010 \\
firm size & -0.099 & 0.003 & -0.106 & 0.004 \\
firm hiring rate & -0.474 & 0.021 & -0.455 & 0.027 \\
market concentration (Herfindahl index) & -0.970 & 0.045 & -0.977 & 0.062 \\
$1 / \delta$ & & & & \\
Pearson Chi-square & \multicolumn{2}{|c|}{15125} & & \multicolumn{2}{c}{9.228} \\
$\mathrm{~N}$ & \multicolumn{2}{|c|}{99608} & & \multicolumn{2}{c}{} \\
\hline
\end{tabular}

Table 5: Shar e of teenagers hir ed by cont inuing fir ms, P oisson regression model. Notes: Controlling for the industry ( 7 dummies), and public or foreign ownership of the company. Firm size is in logs.

The results of the models with and without random effects point in the same direction, and the magnitude of the coefficients changes slightly. A likelihood ratio test compares the random effects estimator with the pooled Poisson estimator, revealing that the panel estimator is more adequate. Therefore, the comments presented below refer just to the model that includes random effects.

After the rise in the youth minimum wage, companies decreased the share of teenagers among their newly-hired workforce (table 5). Note that for both 1988 and 1989, the dummy variable coefficient estimate is negative and statistically significant. Either in 1988 or 1989, the share of teenagers in overall job accessions to continuing firms was around 4 percent lower than in 1986. In that sense, results on the behavior of employers concerning their hiring policy following a rise in the minimum wage lend support to the competitive view of the labor market, as there seems to have been a shift away from teenagers. Larger firms are less likely to recruit teenagers; in a company 10 percent larger, the share of teenagers recruited is 1 percent lower. The inclusion of the hiring rate among the regressors aims at 
further controlling for the impact of the business cycle conditions. Firms with a higher hiring rate are less likely to recruit teenagers; a 1 percentage point increase in the hiring rate decreases by 0.46 percent the share of teenagers hired. The concentration index is meant to proxy for the profitability of the industry; a 1 percentage point increase in the concentration index in the industry decreases the share of teenagers hired by about 1 percent.

\begin{tabular}{|r||c|c|c|c|}
\hline \multicolumn{1}{|c||}{ Variables } & \multicolumn{2}{c|}{ no random effects } & \multicolumn{2}{c|}{ with random effects } \\
\hline & Coef & Std & Coef & Std \\
\hline \hline year 1988 (dummy) & -0.132 & 0.010 & -0.150 & 0.010 \\
year 1989 (dummy) & -0.111 & 0.009 & -0.140 & 0.010 \\
firm size & -0.112 & 0.003 & -0.113 & 0.005 \\
firm hiring rate & -0.123 & 0.016 & -0.121 & 0.020 \\
market concentration (Herfindahl index) & -0.184 & 0.054 & -1.140 & 0.075 \\
$1 / \delta$ & & & & \\
Pearson Chi-square & \multicolumn{2}{|c|}{13890} & & \multicolumn{2}{c}{125397} \\
$\mathrm{~N}$ & \multicolumn{2}{|c|}{125397} & \multicolumn{2}{c}{} \\
\hline
\end{tabular}

Table 6: Share of teenager s separ at ed from cont inuing fir ms, P oisson regression model. Notes: Controlling for the industry (7 dummies), and public or foreign ownership of the company. Firm size is in logs.

However, the share of teenagers in job separations also decreased following the rise in the minimum wage (table 6). Indeed, it was 15 (14 percent) percent lower in 1988 (in 1989) than in 1986. These results contrast with those of the previous table, indicating that the workers affected by a sharp rise in the minimum wage are not over-represented among those afterwards separating from their employers.

Pereira (2002) reached different results, finding that the rise in youth minimum wage reduced employment, as older workers substituted for teenagers after the rise in the youth minimum wage. However, she has modeled net employment changes for a balanced panel of firms observed before and after the policy change, which may bias the results. ${ }^{10}$ Also, her computations did not include any weights for the firms' size (measured, say, by employment), therefore, disregarding the different

\footnotetext{
${ }^{10}$ Pereira includes in her sample approximately 22,000 firms observed in 1986 and 1988 with workers aged 18 to 35, and approximately 20,000 observed in 1986 and 1989. Teenage workers (18 or 19 years old) engaged in the firm in 1986 were bound to join the control group of young adults (aged 20 to 25) one or two years afterwards (respectively), leading to an apparent substitution effect, reinforced in the case of a sharp increase in retention rates, such as the one we have detected. An older control group would reduce this problem, and indeed the results are no longer significant in two out of three regressions if workers aged 30 to 35 are taken as the control group.
} 
impact on overall employment resulting from trends in firms with contrasting sizes. Our separate analysis of job accessions and job separations, looking at the relevance of teenagers in each of these flows, provides further light on the issue than does the analysis of net flows, and overcomes the sampling problems in Pereira's study. Moreover, our coverage of the existing firms in the economy is broader, since we have considered all the firms recruiting workers in the year of 1986, to compare with all the firms that recruited workers in the year of 1988 or 1989 (similarly for separations). In the following section we also take into account new firms and those going out of business.

\subsection{Firm turnover}

We go on to inspect the impact of the rise in the minimum wage on firm closure and firm creation, a topic earlier analyzed by Portugal and Guimarães (1998). This analysis provides a more complete picture of the impact of the minimum wage in an economy with high levels of firm creation and firm destruction (Blanchard and Portugal, 2001).

\begin{tabular}{|r||c|c|}
\hline Variables & Coef & Std \\
\hline \hline year 1988 (dummy) & -0.042 & 0.018 \\
year 1989 (dummy) & -0.041 & 0.018 \\
firm size & -0.113 & 0.005 \\
market concentration (Herfindahl index) & -2.880 & 0.174 \\
$\mathrm{~N}$ & 38138 \\
Pearson Chi-square & 4564 \\
\hline
\end{tabular}

Table 7: Share of teenagers hired by new firms, Poisson regression model. Notes: Controlling for the industry ( 7 dummies), and public or foreign ownership of the company. Firm size is in logs.

Firms set up in 1988 or in 1989, a year or two after the policy change, recruited a 4 percent lower share of teenagers than those set up in 1986 (table 7). As with accessions to continuing firms, these results lend support to the idea that rising minimum wages reduce the demand for the affected workers, as firms set up in 1988 or 1989 increased their tendency to employ older workers when compared to similar firms that had been set up in 1986. Also in line with traditional theory, results 
in table 8 indicate that teenage workers are over-represented in the labor force of firms closing down in 1988, when compared to the situation before the rise in the youth minimum wage. Some support is therefore found for the hypothesis that rising minimum wages may have placed unbearable costs on some firms, leading to teenagers being overrepresented in firms closing down.

\begin{tabular}{|r||c|c|}
\hline Variables & Coef & Std \\
\hline \hline year 1988 (dummy) & 0.050 & 0.023 \\
year 1989 (dummy) & 0.025 & 0.023 \\
firm size & -0.106 & 0.007 \\
market concentration (Herfindahl index) & -2.941 & 0.257 \\
$\mathrm{~N}$ & & \\
Pearson Chi-square & 19203 \\
\end{tabular}

Table 8: Share of t eenager s dismissed from fir ms cl osing down, P oisson regression model. Notes: Controlling for the industry (7 dummies), and public or foreign ownership of the company. Firm size is in logs.

\section{Worker flows: do rising minimum wages increase job attachment?}

A longitudinal perspective from a worker point of view can shed further light on this issue. Following workers over time, we can directly check whether youngsters who were earning sub-minimum wages tended to lose their jobs following the sharp increase in their legal minimum wage. Results reinforce the initial hint, as the rise in the minimum wage did not have the negative employment consequences predicted by traditional economic theory.

Workers aged 16 to 18 and earning sub-minimum wages in 1986 were a year later eligible for a sharp wage rise. Therefore, if the labor market were competitive and they were earning the value of their marginal product, the rise in the minimum wage would price them out of employment. Instead, table 9 shows that, in the age groups affected, the share of workers who remain employed is greater for those initially earning sub-minimum wages than for those at the full minimum. Whereas 66 percent of the youngsters aged 16 to 18 employed at sub-minimum wages in 


\begin{tabular}{|c||c|c|c|c|}
\hline \multicolumn{1}{|c||}{ Age in 1986 } & Wage in 1986 & \multicolumn{3}{|c|}{ Situation in 1987 } \\
\hline & & full-time & part-time & jobless \\
\hline \hline \multirow{1}{*}{$16-18$} & below minimum & 65.96 & 4.24 & 29.80 \\
& at minimum & 59.91 & 3.66 & 36.42 \\
& between min86 and min87 & 75.65 & 4.41 & 19.94 \\
& at or barely above min87 * & 67.87 & 4.10 & 28.03 \\
& above min87 x 1.1 & 71.72 & 4.71 & 23.57 \\
& below minimum & 56.55 & 5.12 & 38.33 \\
& at minimum & 57.63 & 3.26 & 39.11 \\
& between min86 and min87 & 67.66 & 4.79 & 27.54 \\
& at or barely above min87 * & 65.91 & 4.32 & 29.77 \\
& above min87 x 1.1 & 71.66 & 3.70 & 24.64 \\
& below minimum & 56.67 & 6.32 & 37.02 \\
& at minimum & 60.06 & 3.45 & 36.49 \\
& between min86 and min87 & 70.64 & 5.46 & 23.89 \\
& at or barely above min87 * & 71.83 & 4.32 & 23.85 \\
& above min87 x 1.1 & 78.09 & 3.56 & 18.36 \\
& below minimum & 45.61 & 22.85 & 31.53 \\
& at minimum & 23.7 & 3.75 & 72.55 \\
& between min86 and min87 & 56.67 & 6.32 & 37.02 \\
& at or barely above min87 * & 60.06 & 3.45 & 36.49 \\
& above min87 x 1.1 & 70.64 & 5.46 & 23.89 \\
\hline
\end{tabular}

Table 9: E mpl oyment stat us in 1987 of full-time wage-earners in 1986, by age and wage cat egory. Note: * "Barely above" is defined as not exceeding the minimum plus 10 percent.

1986 were still employed full-time a year later, just 60 percent of those earning the full minimum kept their employment status.

If, instead of taking teenagers at the minimum wage as the comparison group, we consider older workers on sub-minimum wages, a similar trend is detected. The share of sub-minimum wage workers remaining in employment is higher in the ages directly affected by the rise in the minimum wage than in older groups.

This section models retention rates from a worker standpoint. We will model the probability that a worker will remain with the same employer. ${ }^{11}$

Before presenting the results, let us briefly discuss alternative specifications for the minimum wage variable and discuss the period under analysis. Three alternatives were used to specify the minimum wage variable:

- Teenagers: a broad specification that considers simply whether a worker is a

\footnotetext{
${ }^{11}$ The probability of losing a job and becoming unemployed has been more frequently debated in the literature and therefore the probability of remaining employed (whether or not with the same employer) was also considered. Its results are in line with the ones reported here.
} 
teenager, to measure the employment impact of a rise in the youth minimum wage.

- sub-minimum wage teenagers: an alternative specification considers whether or not a teenager was a sub-minimum wage worker in the initial period (disregarding how far sub-minimum wages deviate from the minimum wage).

- Wage gap: according to standard competitive reasoning, the probability of remaining employed should be lower the greater the change required in the worker's wage to adjust to the new minimum wage. The distance between the worker's previous wage and the new minimum wage (wage gap) has been used in the literature as an independent variable to capture the impact of changes in the minimum wage (Card and Krueger 1994, Currie and Fallick 1996, Zavodny 2000). It was computed as:

$$
\text { wage } g a p_{i t}=\frac{\min _{t}-w_{86, i}}{w_{86, i}}
$$

for period $t$ and worker $i$, a teenager initially earning sub-minimum wage $w$; it is zero otherwise.

Attention was restricted to workers aged 16 to 35 (teenagers and young adults), since the affected and the comparison groups should be similar (Meyer 1995). Results are robust to the definition of alternative control groups. In particular, if we consider only workers at the minimum (or slightly above the minimum) wage, aged 20 to 35, as the comparison groups, the same results are obtained.

Workers employed in 1986, a year before the rise in the minimum wage, were kept for analysis, to explain their probability of remaining employed in 1988, a year and two months after the rise in the minimum wage had taken place. ${ }^{12}$

The three specifications in tables 10 (for men) and 11 (for women), provide a consistent view of the impact of the minimum wage. Teenagers in general were

\footnotetext{
${ }^{12}$ The probability of remaining employed in 1987 , two months after the rise in the minimum wage, should not be considered because this time lag is too short for the change in the legislation to have taken effect. For example, Neumark (1999) claims that the effect of changes in the minimum wage is felt most strongly with a one-year lag. Analyzing the separations from 1986 to 1989 would be strongly influenced by the military draft for males aged 20-21 in 1989 and therefore we have not considered that longer lag. Note however that 18-year olds in 1986 were already affected by the military service in 1988 .
} 


\begin{tabular}{|r||c|c|c|c|c|c|}
\hline \multicolumn{1}{|c||}{} & \multicolumn{6}{c|}{ Regression estimates } \\
\hline & Coef & Std & Coef & Std & Coef & Std \\
\hline \hline constant & -7.334 & 0.165 & -6.833 & 0.181 & -7.798 & 0.170 \\
teenager & 0.433 & 0.017 & 0.158 & 0.027 & 0.232 & 0.025 \\
submin & & & -0.200 & 0.017 & & \\
submin * teenager & & & 0.500 & 0.034 & & \\
wage gap & & & & & 0.408 & 0.036 \\
age & 0.016 & 0.001 & 0.015 & 0.001 & 0.015 & 0.001 \\
tenure & 0.045 & 0.001 & 0.045 & 0.001 & 0.045 & 0.001 \\
tenure less than 1 & -0.405 & 0.011 & -0.406 & 0.011 & -0.403 & 0.011 \\
apprentice & 0.040 & 0.013 & 0.048 & 0.013 & 0.024 & 0.013 \\
wage86 & 0.597 & 0.016 & 0.555 & 0.018 & 0.645 & 0.017 \\
firm size & 0.097 & 0.002 & 0.095 & 0.002 & 0.097 & 0.002 \\
$\mathrm{~N}$ & 331310 & & 331310 & & 331310 & \\
Chi-square & 33490 & & 33760 & & 33618 & \\
\hline
\end{tabular}

Table 10: Probabil it y of remaining with the same empl oyer from 1986 t o 1988, men ( $\mathrm{og}$ it model ). The regression controls for schooling ( 7 dummies), industry ( 7 dummies), and foreign or public ownership of the company.

more likely to keep their jobs, from 1986 to 1988, than were older workers. As their minimum wage was raised, compressing the bottom part of the wage distribution, the expected benefits from searching for a new job decline, and thus there is now less incentive to quit the job. Workers with sub-minimum wages are more likely to leave their job (see the coefficient on the sub-minimum variable), which could be partly associated with poor job satisfaction resulting from a low wage. However, teenagers earning sub-minimum wages in 1986 are much more likely to remain with their employer than sub-minimum-wage workers in general, or teenagers in general. The change in the legislation led to a wage raise that may have increased job attachment for the affected group of workers. The wage gap variable (specification 3 ) is also positive and highly significant, revealing that teenagers initially earning the lowest wages, and therefore subject to the highest wage raise, are the workers most likely to stick to their employers. ${ }^{13}$

What if sub-minimum wages had not increased? Would teenagers have shown the same pattern of behavior anyway? To further check if the differences in behavior that we are capturing are indeed due to changes in the minimum wage

\footnotetext{
${ }^{13}$ The wage of the worker was included among the regressors. Following Card and Krueger (1995) and Abowd et al. (2000), it is intended to capture heterogeneity in labor force attachment across the wage distribution.
} 


\begin{tabular}{|r||c|c|c|c|c|c|}
\hline \multicolumn{1}{|c||}{} & \multicolumn{6}{c|}{ Regression estimates } \\
\hline & Coef & Std & Coef & Std & Coef & Std \\
\hline \hline constant & -6.583 & 0.230 & -5.434 & 0.257 & -6.747 & 0.238 \\
teenager & 0.163 & 0.020 & 0.058 & 0.032 & 0.100 & 0.031 \\
submin & & & -0.179 & 0.016 & & \\
submin * teenager & & & 0.220 & 0.038 & & \\
wage gap & & & & & 0.132 & 0.048 \\
age & -0.006 & 0.001 & -0.006 & 0.001 & -0.006 & 0.001 \\
tenure & 0.041 & 0.001 & 0.041 & 0.001 & 0.041 & 0.001 \\
tenure less than 1 & -0.366 & 0.015 & -0.367 & 0.015 & -0.366 & 0.015 \\
apprentice & 0.032 & 0.014 & 0.050 & 0.015 & 0.028 & 0.014 \\
wage86 & 0.600 & 0.023 & 0.492 & 0.026 & 0.617 & 0.024 \\
firm size & 0.102 & 0.003 & 0.100 & 0.003 & 0.102 & 0.003 \\
$\mathrm{~N}$ & 220778 & & 220778 & & 220778 & \\
Chi-square & 13237 & & 13372 & & 13245 & \\
\hline
\end{tabular}

Table 11: Probability of remaining with the same employer from 1986 t 0 1988, wo men (l o git model). The regression controls for schooling ( 7 dummies), industry (7 dummies), and foreign or public ownership of the company.

legislation, and not due to permanent contrasts across the groups of workers, a different time period was considered as well - one when no change in the legislation had occurred (1984 to 1986). Worker retentions from 1984 to 1986 and from 1986 to 1988 were therefore compared, by pooling the data for both periods. The impact of the change in the minimum wage was captured by interacting a dummy variable for the 1986-88 period, after the change in the legislation, with the minimum wage variable.

Tables 12 (for men) and 13 (for women) shed additional light on the previous results. The first specification indicates that, after the increase in the minimum wage, teenagers reinforced their higher probability to keep their jobs, when compared to older workers. The second specification similarly highlights that the change in the legislation led to increased job attachment for the affected group of workers, sub-minimum wage teenagers. A similar picture is drawn by the results of the third specification. It is worth noting that these results reveal that teenage males show higher retention rates than do their older counterparts, regardless of the period being considered. We are convinced that this pattern is largely produced by the age when male youth are drafted into the (mandatory) military service. 


\begin{tabular}{|c|c|c|c|c|c|c|}
\hline & \multicolumn{6}{|c|}{ Regression estimates } \\
\hline & Coef & Std & Coef & Std & Coef & Std \\
\hline constant & -7.465 & 0.112 & -5.454 & 0.132 & $\begin{array}{c}-8.232 \\
\end{array}$ & 0.117 \\
\hline year (dummy for after change minw) & -0.249 & 0.005 & -0.393 & 0.007 & -0.233 & 0.005 \\
\hline teenager & 0.358 & 0.013 & 0.158 & 0.026 & 0.150 & 0.016 \\
\hline submin & & & -0.260 & 0.008 & & \\
\hline submin $*$ teenager & & & 0.209 & 0.027 & & \\
\hline $\begin{array}{r}\text { wage gap } \\
\text { year*teenager }\end{array}$ & 0.190 & 0.017 & & & 0.339 & 0.018 \\
\hline $\begin{array}{r}\text { year*submin*teenager } \\
\text { year*wage gap }\end{array}$ & & & 0.377 & 0.020 & 0.334 & 0.024 \\
\hline age & 0.020 & 0.001 & 0.018 & 0.001 & 0.018 & 0.001 \\
\hline tenure & 0.059 & 0.001 & 0.058 & 0.001 & 0.058 & 0.001 \\
\hline tenure less than 1 & -0.463 & 0.007 & -0.461 & 0.007 & -0.462 & 0.007 \\
\hline apprentice & 0.078 & 0.009 & 0.070 & 0.009 & 0.054 & 0.009 \\
\hline wage & 0.605 & 0.011 & 0.433 & 0.013 & 0.683 & 0.012 \\
\hline firm size & 0.118 & 0.002 & 0.115 & 0.002 & 0.117 & 0.002 \\
\hline $\mathrm{N}$ & 763270 & & 763270 & & 763270 & \\
\hline Chi-square & 108158 & & 109295 & & 108639 & \\
\hline
\end{tabular}

Table 12: Probabil it y of remaining wit h the same empl oyer, from 1984 to 1986 and from 1986 to 1988, pool ed dat a, men (l o git model). The regression controls for schooling (7 dummies), industry (7 dummies), and foreign or public ownership of the company.

These results contrast with those obtained in several previous studies. Stewart (2002) found no impact on employment for the affected group after the introduction of the minimum wage in the UK. In the work by Currie and Fallick (1996) for the USA, the affected group of workers was found to have lower probability of remaining employed than low-wage workers who were not affected by the rise in the minimum wage. Similarly, the larger the wage gap, and therefore the larger the wage increase due, the lower the probability that the worker remained employed, a result shared by Linneman (1982). Zavodny (2000) found that the probability to remain employed in the USA following a rise in the minimum wage is lower for low-wage teens than for high-wage teens. Abowd et al. (2000) also found that job-loss effects are more pronounced for workers directly affected by the rise in the minimum wage than for those initially marginally above the new minimum wage.

Neumark and Wascher (1995a, 1995b) explicitly considered supply side effects. They concluded that following a rise in the minimum wage, high-skill teenagers 


\begin{tabular}{|r||c|c|c|c|c|c|}
\hline \multicolumn{1}{|c||}{} & \multicolumn{6}{c|}{ Regression estimates } \\
\hline constant & Coef & Std & Coef & Std & Coef & Std \\
\hline \hline teenager & -6.913 & 0.159 & -6.129 & 0.190 & -7235 & 0.166 \\
submin & 0.070 & 0.016 & 0.075 & 0.031 & 0.020 & 0.022 \\
year (dummy for after change minw) & -0.256 & 0.007 & -0.320 & 0.010 & -0.248 & 0.007 \\
submin * teenager & & & -0.095 & 0.011 & & \\
wage gap & & & -0.007 & 0.034 & & \\
year*teenager & 0.156 & 0.022 & & & 0.100 & 0.025 \\
year*submin*teenager & & & 0.239 & 0.025 & & \\
year*age gap & & & & & 0.247 & 0.032 \\
age & -0.008 & 0.001 & -0.008 & 0.001 & -0.008 & 0.001 \\
tenure & 0.052 & 0.001 & 0.052 & 0.001 & 0.052 & 0.001 \\
tenure less than 1 & -0.384 & 0.010 & -0.385 & 0.010 & -0.386 & 0.009 \\
apprentice & 0.045 & 0.010 & 0.042 & 0.010 & 0.039 & 0.010 \\
wage & 0.631 & 0.016 & 0.564 & 0.018 & 0.664 & 0.017 \\
firm size & 0.142 & 0.002 & 0.141 & 0.002 & 0.141 & 0.002 \\
$\mathrm{~N}$ & 478213 & & & & & \\
Chi-square & 42404 & & 478213 & & 478213 & \\
\hline
\end{tabular}

Table 13: Probabil ity of remaining with the same employer, from 1984 to 1986 and from 1986 to 1988, pooled data, women (logit model). The regression controls for schooling ( 7 dummies), industry ( 7 dummies), and foreign or public ownership of the company.

may leave school to start working, replacing low-skilled teens, whose marginal revenue falls below the new minimum wage. According to Neumark and Wascher, the weak youth disemployment effects detected by some studies could simply result from the fact that teenagers are encouraged to leave school, driving out of work less-skilled teens previously employed. Thus, there would be strong disemployment effects on teenagers already working, but they would not be captured by the analysis simply because there would be rising demand (and supply) for moreskilled youngsters. Explicitly modeling the retention rates, we do not find support for that hypothesis, as the retention rate is higher for teens earning sub-minimum wages than for the unaffected groups of workers. Moreover, the fact that following the rise in the youth minimum wage, there is a decrease in the opportunities for job accessions by teenagers relative to older workers, as shown in section 5, reducing the impact that the minimum wage might have of pulling teenagers out of school. 


\section{A theoretical explanation based on job search frictions}

We now turn to the discussion of our results from a theoretical point of view. After disputing the business cycle explanation for the detected trends, we present the major characteristics of the model by Burdett and Mortensen (1998), since it provides clear predictions, in particular on the impact of the firm's wage level on quitings and hirings, and the impact of the minimum wage on employment, which are consistent with the empirical results of this paper. ${ }^{14}$

Could it all have been driven by the business cycle, with economic expansion explaining the rise in teenage employment? Were youngsters fueling the rising employment in the economy? We believe that this was not the case. First, because the periods pre- and post- rise in the minimum wage did not differ in terms of economic growth, as the economy was already growing at a fast pace before the rise in the minimum wage, from 1985 to 1986. Second, the unemployment rate was around 9 percent in 1986, and so there was a pool of older workers seeking jobs. Third, our methodology partially controls for business cycle effects that might have influenced the group of workers affected by the change in the legislation and similar workers that were included in the comparison group. In fact, what we are explaining is the share of teenagers in the flow of hirings or dismissals. The total flow is certainly influenced by the business cycle, but there are no strong reasons to believe that the share of teenagers in that flow should be. Even if it is, the use of hiring and separation rates at the firm level as explanatory variables would, in our view, attenuate the business cycle contamination of the results. Fourth, and most important, if business cycle effects were driving the rise in youth employment, it can be argued that job accessions by teenagers would have increased relative to older workers. On the contrary, we find that it decreased, and youngsters' rising employment was driven mainly by a decline in job separations.

\footnotetext{
${ }^{14}$ Cahuc et al. (2001) have built a model where the type of technology used by the firm and the bargaining process over wages play a central role allowing employment of the unskilled to rise following an increase in the minimum wage. The theoretical model by Dickens et al. (1999), where firms have monopsony power, and Lang and Kahn's (1998) bilateral search model, allow as well for a positive impact of the minimum wage on employment. However, no predictions are made concerning gross worker flows at the firm level. For an empirical test of the predictions of Burdett and Mortensen's model, see Van der Berg and Ridder (1998).
} 
Burdett and Mortensen (1998) have developed an equilibrium wage dispersion search model that nicely matches the observed characteristics of this experiment. ${ }^{15}$ In their game, firms post wages and workers search. They can search on the job or while unemployed, taking sequential random draws from the distribution of wage offers, with the parameter $\lambda$ of a Poisson distribution as the rate of arrival of offers. Job-worker matches are exogenously destroyed at the rate $\delta$, driving the worker into unemployment. Workers are heterogenous with respect to the utility while unemployed, $b$, which determines their reservation wage, and $H(b)$ is the share of workers with reservation wage no greater than $b$. A wage offer is accepted by an unemployed worker if it exceeds his reservation wage. A wage offer is accepted by an employed worker if it exceeds his current wage. $F(w)$ is the distribution of wage offers in the economy, and $G(w)$ is the distribution of workers' wages. There are $m$ workers in the economy and total employment is $(m-u)$, where $u$ is total unemployment, a function of the distribution of wage offers and workers' reservation wages. The number of workers employed at wages no greater than $w$ is therefore $G(w)(m-u)$.

Firm-level worker flows, crucial in our empirical analysis, are derived. The separation equation giving the flow of workers from employment at wages no greater than $w$ into unemployment is computed as:

$$
\delta G(w)(m-u)
$$

The job turnover equation describes the job to job flow of workers, moving from a firm paying a wage no greater than $w$ to a higher paying one, is:

$$
\lambda[1-F(w)] G(w)(m-u) .
$$

Note that the voluntary quit rate, $\lambda(1-F(w))$, decreases with the wage offered - better-paying employers face lower quit rates, a theoretical result of great importance in explaining the detected empirical patterns.

\footnotetext{
${ }^{15}$ Here, we basically take Burdett and Mortenson derivations as an off-the-shelf model, with a view to provide an interpretation of our results.
} 
The flow of unemployed workers into firms offering a wage no greater than $w$ is given by the hiring equation:

$$
\lambda_{\underline{b}}^{\mathbf{Z}_{w}}[F(w)-F(x)] d u(x \mid F),
$$

noting that $d u(b \mid F)$ is the measure of unemployed workers with reservation wage $b$, and $[F(w)-F(b)]$ is the probability that an offer received by a type $b$ worker is acceptable and less than or equal to $w$.

From the equality, in a steady-state, of the entry and exit flows of workers, Burdett and Mortensen derive:

- a unique distribution of wages $G(w)$;

- the function $\ell(w \mid F)$, the number of workers available to a firm offering wage $w$, given the wage offers of other firms.

Importantly, the number of workers available to a firm is increasing in $w$. Therefore, firms offering higher wages are able to attract more workers. They are thus larger ones.

- a distribution of wage offers $F(w)$ by profit-maximizing firms. Profit per employee is $(p-w)$, with $p$ denoting the revenue generated by each worker, and the total profit of the firm is thus $(p-w) \ell(w \mid F){ }^{16}$

Offering a higher wage therefore involves a trade-off to the company - a smaller profit per employee is generated, but a larger workforce is attracted. There are diseconomies of scale in hiring workers. Since in equilibrium all wage offers must yield the same profit, a firm may choose a policy of low wage and a small workforce, with high worker turnover, or a high wage and a larger workforce, with lower worker turnover. ${ }^{17}$

Burdett and Mortensen progress within this framework to address the impact of the minimum wage. In situations where the wage offered is below the worker

\footnotetext{
${ }^{16}$ Jobs are homogenous.

${ }^{17}$ The possibility of a single market wage, or any other non-continuous wage distribution, is ruled out. Indeed, if firms were bunched together at a wage $\hat{w}$, any firm offering a slightly higher wage would slightly reduce its profit per employee, but would attract a much larger workforce, therefore raising its total profit.
} 
reservation wage $(w<b)$, the worker will not accept the offer, even though his productivity may be larger than his opportunity cost $(p>b)$. Inefficient unemployment is thus generated. Inefficient unemployment is increasing in the degree of frictions existing in the labor market, $\frac{\delta}{\lambda}=k$, the ratio of the job-worker match destruction rate and the rate of arrival of wage offers. The extent of labor market frictions, $k$, therefore provides a measure of the employers' monopsony power. Raising the minimum wage shifts the wage offer distribution and reduces inefficient unemployment. The model therefore explicitly predicts that increases in the minimum wage can reduce unemployment and raise employment. ${ }^{18}$

\section{Conclusion}

This study goes beyond the explanation of net employment changes by worker types at the firm level following a rise in the minimum wage. It studies gross worker flows - both accessions and separations - in continuing firms, as well as in new firms and those going out of business, relying on a matched employer-employee panel data set. Decomposition of the changes in employment by its sources can help reconcile some of the evidence that has previously been presented in the literature as contradictory, helping to disentangle the minimum wage puzzle.

It has previously been documented that low-wage workers in general have higher turnover rates, either because they have fewer incentives to remain with their employer, thus being more prone to quit, or because they are the first to be dismissed in case of adverse conditions. The theoretical model of Burdett and Mortensen provides a neat theoretical framework for this pattern. Our evidence is consistent with that view. A general pattern emerges, with workers earning below the minimum generally presenting lower retention rates, and those earning higher wages

\footnotetext{
${ }^{18}$ Another line of reasoning would consider adjustment costs. New firms, which are unconstrained in their recruitment policy, would react to the change in factor prices, recruiting a lower share of teenagers. On the contrary, firms that were already in business were partially constrained by employment firing costs and by sunk costs incurred in hiring and training of teenagers - dismissing a teenager who has been with the company for one or two years, to recruit an older worker at the same wage, might not be a profit-maximizing option. There is thus an inaction band, where the firm decides not to react to a change in the factor prices. The substitution effect could therefore have been partially held back. A scale effect is likely to operate nevertheless, and some firms might reduce their scale of operation, reducing job accessions by teenagers.
} 
revealing higher propensity to remain in employment.

Concentrating on the impact of changes in the minimum wage, our results show that the share of teenagers among newly hired workers in continuing firms decreases, just as new firms decrease the share of youngsters they hire. On the other hand, the share of teenagers in job separations in continuing firms decreases sharply following the rise in the minimum wage. From a worker perspective, we find that teenagers subject to a high wage increase resulting from the change in the minimum wage are much more prone to keep their job than comparable groups. This result points to the relevance of supply side factors, as job attachment for lowwage youngsters may rise following an increase in their minimum wage, reducing the high job turnover that is characteristic of low-wage workers.

The main impact of the 1987 minimum wage change in the Portuguese labor market therefore seems to be the reduction of quitings and in general the reduction of separations from the employer, which compensates for the reduction of accessions (to new and continuing firms). 


\section{R eferences}

A bowd, John M., Francis Kramarz, David N. Margol is and Thomas P hil ippon (2000). The tale of two countries: minimum wages and employment in France and the United States. Mimeo.

B I anchard, O I ivier and Pedro Port ugal (2001). What hides behind an unemployment rate: comparing Portuguese and U.S. labor markets. American Economic Review, 91(1): 187-207.

Brown, Charles, Curt is Gil roy and Andrew Kohen (1982). The effect of the minimum wage on employment and unemployment. Journal of Economic Literature, 20: 487-528.

B urdet t, K ennet h and Dale T. Mortensen (1998). Wage differentials, employer size and unemployment. International Economic Review, 39(2): 257-273.

B urkhauser, Richard V., Kenneth A. Couch and David C. W it tenburg (2000). A reassessment of the new economics of the minimum wage literature with monthly data from the Current Population Survey. Journal of Labor Economics, 18(4): 653-701.

C ahuc, P., A . Saint -M art in and A . Zyl ber berg (2001). The consequences of the minimum wage when other wages are bargained over. European Economic Review, 45(2): 337-352.

Camer on, A. Colin and Pravin K. Trivedi (1998). Regression Analysis of Count Data. Cambridge: Cambridge University Press.

Card, David and A I an B. Krueger (1994). Minimum wages and employment: a case study of the fast-food industry in New Jersey and Pennsylvania. American Economic Review, 84(4): 772-793.

Card, David and A Ian B. Krueger (1995). Myth and Measurement: The 
New Economics of the Minimum Wage. Princeton; NJ: Princeton University Press.

Card, David and A I an B. Krueger (2000). Minimum wages and employment: a case study of the fast-food industry in New Jersey and Pennsylvania: reply. American Economic Review, 90(5): 1397-1420.

Currie, Janet and Bruce C. Fall ick (1996). The minimum wage and the employment of youth: evidence from the NLSY. Journal of Human Resources, 31(2): 404-428.

Deere, Donald, Kevin M. M ur phy and Finis W el ch (1995). Employment and the 1990-1991 minimum-wage hike. American Economic Review, 85(2): 232-237.

Dickens, Richard, Stephen M achin and Alan Manning (1998). Estimating the effect of minimum wages on employment from the distribution of wages: a critical view. Labour Economics, 5: 109-134.

Dickens, Richard, Stephen Machin and Alan Manning (1999). The effects of minimum wages on employment: theory and evidence from Britain. Journal of Labor Economics, 17(1): 1-22.

Dolado, Juan, Francis Kramarz, Stephen Machin, Alan Manning, David Margol is and Coen Teulings (1996). The economic impact of minimum wages in Europe. Economic Policy, 23: 318-357.

K at Z, Lawrence F . and A I an B. K rueger (1992). The effect of the minimum wage on the fast-food industry. Industrial and Labor Relations Review, 46(1): 6-21.

K ennan, J ohn (1995). The elusive effects of minimum wages. Journal of Economic Literature, 33(4): 1950-1965.

Lang, K evin and Shul amit K ahn (1998). The effect of minimum-wage laws on the distribution of employment: theory and evidence. Journal of Public 
Economics, 69: 67-82.

Linneman, P et er (1982). The economic impacts of minimum wage laws: a new look at an old question. Journal of Political Economy, 90(3): 443-469.

Machin, Stephen and Alan Manning (1996). Employment and the introduction of a minimum wage in Britain. Economic Journal, 106(436): 667-676.

M eyer, B ruce (1995). Natural and quasi-experiments in economics. Journal of Business and Economic Statistics, 13(2): 151-161.

Meyer, Robert H. and David A. W ise (1983a). Discontinuous distributions and missing persons: the minimum wage and unemployed youth. Econometrica, 51(6): 1677-1698.

Meyer, Robert H. and David A. W ise (1983b). The effects of the minimum wage on the employment and earnings of youth. Journal of Labor Economics, 1(1): $66-100$.

N eumark, David (1999). The employment effects of recent minimum wage increases: evidence from a pre-specified research design. National Bureau of Economic Research working paper 7171. Cambridge, MA: NBER.

N eumark, David and W il I iam Wascher (1995a). Minimum wage effects on employment and school enrollment. Journal of Business and Economic Statistics, 13(2): 199-206.

N eumark, David and W il I iam W ascher (1995b). Minimum wage effects on school and work transitions of teenagers. American Economic Review, 85(2): 244-249.

N eumark, David and W il I iam W ascher (2000). Minimum wages and employment: a case study of the fast-food industry in New Jersey and Pennsylvania: comment. American Economic Review, 90(5): 1362-1396.

Pereira, Sonia Cecil ia (2002). The impact of minimum wages on youth employment in Portugal. European Economic Review (forthcoming). 
Portugal. M inistério do Trabalho e da Solidariedade (1984-1989). Quadros de Pessoal. Data in magnetic medium.

Port ugal, Pedro and Paul o Guimarães (1998). The influence of minimum wages and local labor market conditions on the entry and exit of plants. Mimeo.

St ewart, M ar k B . (2002). The impact of the introduction of the UK minimum wage on the employment probabilities of low wage workers. Mimeo, University of Warwick.

Van der Berg, Gerard J. and Geert Ridder (1998). An empirical equilibrium search model of the labor market. Econometrica, 66(5): 1183-1221.

Zavodny, M adel ine (2000). The effect of the minimum wage on employment and hours. Labour Economics, 7: 729-750. 


\section{A ppendix A: Data set and concepts used}

\section{Data set}

This study is based on a longitudinal data set matching firms and workers in the Portuguese economy, from 1985 to 1993. Both units can be followed over time. The data set is gathered every year by the Ministry of Employment and Solidarity, based on an inquiry that every establishment with wage-earners is legally obliged to fill in. The response rate is extremely high, and in fact the population of firms with wage-earners in manufacturing and the services private sector is covered. No restrictions are imposed on the wage-earners covered (for example, there are no age restrictions and no limits beyond which wages would not be reported). Reported data include the firm's location, industry, employment, sales, ownership, legal setting, and the worker's gender, age, skill, occupation, schooling, admission date, earnings, duration of work, as well as the mechanism of wage bargaining. Each firm entering the database is assigned a unique identifying number and it can thus be followed over time. The Ministry implements several checks to ensure that a firm that has already reported to the database is not assigned a different identification number. The worker identification number is based on a transformation of his/her social security number.

\section{Wages}

The data base reports the gross monthly wage, split into the following components: base wage, regularly paid subsidies, overtime work and irregularly paid subsidies. Normal and overtime hours of work are reported, as well.

The minimum wage is defined in Portugal as a monthly wage rate. Therefore,

only full-time wage-earners were considered in the analysis and the wage refers to the gross base monthly wage. 


\section{New firms, continuing firms and those gone out of business}

A firm is considered a new one if it had never previously reported to Quadros de Pessoal. A firm is reported as having gone out of business the first year it fails to report if it never returns to the data base. A firm is considered a continuing one if it reported both in the previous and the current periods. The regressions on the share of teenagers recruited by continuing firms include all continuing firms that recruited workers in the age bracket 16-35. Similarly, the regressions for dismissals by continuing firms include all the continuing firms that dismissed workers in the age bracket 16-35.

\section{A ppendix B: Changes in the minimum wage legislation}

Apart from the changes in the age coverage of the minimum wage, which have been described in the text, the minimum wage legislation has undergone other changes, which can be summarized as follows: ${ }^{19}$

- Industry coverage: in 1977, it was extended to cover workers in agriculture, though their wage rate was lower; the following year, household service was covered as well, at a rate lower than agriculture. In 1991, the agricultural and general minimum wages were harmonized and in 1998 the same was applied to household service.

Raising the minimum wage for agriculture and for household work to the general level took place gradually and the full harmonization was therefore highly predictable. As such, these changes in the legislation do not provide adequate conditions for economic analysis.

- Firm size coverage: small firms outside agriculture with fewer than 5 workers were allowed to pay the lowest minimum, set for agriculture, a possibility introduced in 1978 and revoked in 1991. Before 1978, several regimes had existed: in 1974, firms with fewer than 5 workers were exempted; in 1975

\footnotetext{
${ }^{19}$ Throughout the period, minimum wage reductions applied to handicapped workers.
} 
and 1976, those with fewer than 10 workers were exempted, as well; in 1977 firms with fewer than 10 workers outside agriculture were allowed to pay the minimum set for agriculture, if they proved they were in a difficult financial situation.

On request, firms claiming that the application of the new minimum wage would impose an unbearable rise in labor costs, were allowed to pay the minimum wage set for agriculture. This possibility was introduced in 1978. In 1987, only firms with fewer than 50 workers were eligible for this reduction, and the firm size benchmark was lowered to 30 workers in 1988, 20 workers in 1989, and revoked in 1990.

Since the minimum wage for agriculture and the general one had been gradually harmonized, the abolition of these exemptions did not lead to a remarkable rise in the applicable minimum wage.

\section{Appendix C: Additional tables}

\begin{tabular}{|r||c|c|c|c|}
\hline Age & 1986 & 1987 & 1988 & 1989 \\
\hline \hline 16 & 0.838 & 0.847 & 0.837 & 0.835 \\
17 & 0.779 & 0.774 & 0.761 & 0.761 \\
18 & 0.625 & 0.617 & 0.597 & 0.583 \\
19 & 0.493 & 0.503 & 0.483 & 0.459 \\
20 & 0.349 & 0.367 & 0.372 & 0.357 \\
21 & 0.250 & 0.281 & 0.283 & 0.286 \\
22 & 0.197 & 0.213 & 0.230 & 0.224 \\
23 & 0.153 & 0.175 & 0.182 & 0.184 \\
24 & 0.120 & 0.138 & 0.150 & 0.147 \\
$25-29$ & 0.058 & 0.073 & 0.082 & 0.090 \\
$30-34$ & 0.025 & 0.034 & 0.034 & 0.000 \\
$35-39$ & 0.016 & 0.022 & 0.022 & 0.000 \\
$40-65$ & 0.010 & 0.014 & 0.012 & 0.000 \\
Total & 0.104 & 0.116 & 0.122 & 0.127 \\
\hline
\end{tabular}

Table 14: Share of apprent ices, by age group, 1985-1989. Source: Computations based on Portugal, MTS (1986-1989). 


\section{IZA Discussion Papers}

\begin{tabular}{|c|c|c|c|c|}
\hline No. & Author(s) & Title & Area & Date \\
\hline 527 & J. C. van Ours & The Locking-in Effect of Subsidized Jobs & 4 & $07 / 02$ \\
\hline 528 & $\begin{array}{l}\text { P. Manzini } \\
\text { M. Mariotti }\end{array}$ & $\begin{array}{l}\text { Arbitration and Mediation: An Economic } \\
\text { Perspective }\end{array}$ & 3 & $07 / 02$ \\
\hline 529 & $\begin{array}{l}\text { J. M. Orszag } \\
\text { D. Snower }\end{array}$ & Incapacity Benefits and Employment Policy & 3 & $07 / 02$ \\
\hline 530 & $\begin{array}{l}\text { M. Karanassou } \\
\text { D. Snower }\end{array}$ & Unemployment Invariance & 3 & $07 / 02$ \\
\hline 531 & $\begin{array}{l}\text { M. Karanassou } \\
\text { H. Sala } \\
\text { D. Snower }\end{array}$ & $\begin{array}{l}\text { Unemployment in the European Union: A } \\
\text { Dynamic Reappraisal }\end{array}$ & 3 & $07 / 02$ \\
\hline 532 & $\begin{array}{l}\text { J. M. Orszag } \\
\text { D. Snower }\end{array}$ & $\begin{array}{l}\text { From Unemployment Benefits to Unemployment } \\
\text { Accounts }\end{array}$ & 3 & $07 / 02$ \\
\hline 533 & $\begin{array}{l}\text { S. Fölster } \\
\text { R. Gidehag } \\
\text { M. Orszag } \\
\text { D. Snower }\end{array}$ & Assessing Welfare Accounts & 3 & $07 / 02$ \\
\hline 534 & $\begin{array}{l}\text { A. Lindbeck } \\
\text { D. Snower }\end{array}$ & The Insider-Outsider Theory: A Survey & 3 & $07 / 02$ \\
\hline 535 & $\begin{array}{l}\text { P. Manzini } \\
\text { D. Snower }\end{array}$ & $\begin{array}{l}\text { Wage Determination and the Sources of } \\
\text { Bargaining Power }\end{array}$ & 3 & $07 / 02$ \\
\hline 536 & $\begin{array}{l}\text { M. Orszag } \\
\text { D. Snower }\end{array}$ & Pension Taxes versus Early Retirement Rights & 3 & $07 / 02$ \\
\hline 537 & $\begin{array}{l}\text { J. M. Orszag } \\
\text { D. Snower }\end{array}$ & $\begin{array}{l}\text { Unemployment Vouchers versus Low-Wage } \\
\text { Subsidies }\end{array}$ & 3 & $07 / 02$ \\
\hline 538 & $\begin{array}{l}\text { M. Orszag } \\
\text { D. Snower }\end{array}$ & The Pension Transfer Program & 3 & $07 / 02$ \\
\hline 539 & $\begin{array}{l}\text { Y.-F. Chen } \\
\text { D. Snower } \\
\text { G. Zoega }\end{array}$ & $\begin{array}{l}\text { Labour-Market Institutions and Macroeconomic } \\
\text { Shocks }\end{array}$ & 3 & $07 / 02$ \\
\hline 540 & $\begin{array}{l}\text { G. S. Epstein } \\
\text { A. Kunze } \\
\text { M. E. Ward }\end{array}$ & $\begin{array}{l}\text { High Skilled Migration and the Exertion of Effort } \\
\text { by the Local Population }\end{array}$ & 1 & $08 / 02$ \\
\hline 541 & $\begin{array}{l}\text { B. Cockx } \\
\text { M. Dejemeppe }\end{array}$ & $\begin{array}{l}\text { Do the Higher Educated Unemployed Crowd Out } \\
\text { the Lower Educated Ones in a Competition for } \\
\text { Jobs }\end{array}$ & 2 & $08 / 02$ \\
\hline 542 & M. Frölich & Programme Evaluation with Multiple Treatments & 6 & 08/02 \\
\hline 543 & $\begin{array}{l}\text { J. Darby } \\
\text { R. A. Hart }\end{array}$ & $\begin{array}{l}\text { Wages, Productivity, and Work Intensity in the } \\
\text { Great Depression }\end{array}$ & 5 & $08 / 02$ \\
\hline 544 & $\begin{array}{l}\text { P. Portugal } \\
\text { A. R. Cardoso }\end{array}$ & $\begin{array}{l}\text { Disentangling the Minimum Wage Puzzle: An } \\
\text { Analysis of Worker Accessions and Separations }\end{array}$ & 3 & $08 / 02$ \\
\hline
\end{tabular}

An updated list of IZA Discussion Papers is available on the center's homepage www.iza.org. 